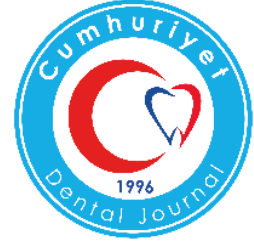

\section{THE PLAQUE REMOVAL EFFECTIVENESS OF POWERED AND MANUAL TOOTH BRUSH IN CHILDREN: A PILOT STUDY}

\author{
Çocuklarda Otomatik ve Manuel Diş Fırçalarının Plak Uzaklaştırma Etkinliği: Bir \\ Pilot Çalışma \\ Pilot Çalışma
}

Müesser Ahu DURHAN ${ }^{1}$, Merve ULUAKAY $^{2}$, Betül KARGUL ${ }^{1}$

$\begin{array}{ll}\text { Makale Kodu/Article Code } & : 480461 \\ \text { Makale Gönderilme Tarihi } & : 08.11 .2018 \\ \text { Kabul Tarihi } & : 10.12 .2018\end{array}$

\section{ABSTRACT}

Objective: Aim of this study was to compare the plaquereducing effectiveness of powered and manual tooth brushing in a small group of children.

Materials and Methods: Ten children aged between 7 to 10 years old were included the study. Each child firstly used manual tooth brush (ORAL B Stages for children). After two weeks children were asked to use powered tooth brush (ORAL-B TRIUMPH 5000 SMART GUIDE) for two weeks. Turesky modification of the Quigley and Hein Plaque Index (TQHPI) and Approximal Plaque Index (API) scores were recorded every two weeks. Friedman test and Wilcoxon signed rank test were used for comparison the jaws and powered brush /manual brush. Significance at $\mathrm{p}<0.05$ were considered.

Results: The whole mouth TQHPI and API were significantly different at after Powered Tooth brushing $(\mathrm{p}=0.005, \mathrm{p}=0.012)$. Statistics determined the most significant relationship was observed between baselinepost powered brushing and between manual-powered brushing in both TQHPI and API values $\left(\mathrm{p}=0.008^{* *}\right.$, $\mathrm{p}=0.005^{* *}, \mathrm{p}=0.018^{*}, \mathrm{p}=0.012^{*}$ ).

Conclusion: Considering the results of the pilot study; it shows that it is more effective in removing dental plaque in both automatic and manual tooth brushing. Therefore, powered tooth brush can also be recommended for children to increase the oral health.

Key Words: Powered Tooth Brush, Children, Oral Health

\section{öz}

Amaç: Bu çalışmanın amacı bir grup çocukta otomatik ve manuel diş firçalamanın dental plak uzaklaştırmadaki etkinliğini karşılaştırmaktır.

Gereç ve Yöntemler: Çalışmaya 7 ile 10 yaş arası 10 çocuk dahil edilmiştir. Her çocuk ilk önce 2 hafta süre ile manuel diş firçası kullanmıştır (ORAL B Stages). İki hafta sonunda çocuklarda plak indeksleri ölçülmüştür. Sonrasında çocuklara iki hafta standart diş firçalamaya devam etmeleri istenmiş ve bu iki haftanın sonunda çocuklardan otomatik diş firçasına (ORAL-B TRIUMPH 5000 SMART GUIDE) geçmeleri söylenmiştir. Quigley ve Hein Plaque Index (TQHPI) ve Approximal Plaque Index (API) skorlarının Turesky modifikasyonu her iki haftada bir kaydedilmiştir. Otomatik firça/manuel firçaların karşılaştırılmasında Friedman testi ve Wilcoxon işaretli rank testi kullanılmış, anlamlılık p <0,05 olarak kabul edilmiştir.

Bulgular: Tüm ağız dental plak ölçümü incelendiğinde otomatik ve manuel diş firçalama arasında; TQHPI ve API'lerine göre istatistiksel olarak anlamlı farkl11ık belirlenmiştir ( $\mathrm{p}=0,005, \mathrm{p}=0,012)$. İstatistiksel analiz; başlangıç dental plak ölçümü ve otomatik firça, manuel ve otomatik diş firçası arasında ikili karşılaştırmalar yapıldığında TQHPI ve API'lerine göre ileri derecede anlamlı farklılık olduğunu göstermiştir $\left(\mathrm{p}=0,008^{* *}\right.$, $\left.\mathrm{p}=0,005^{* *}, \mathrm{p}=0,018^{*}, \mathrm{p}=0,012^{*}\right)$.

Sonuç: Pilot çalışma sonuçları göz önünde bulundurulduğunda; otomatik ve manuel diş firçalamanın ikisinin de dental plağın uzaklaştırılmasında etkili olduğunu göstermektedir. $\mathrm{Bu}$ sebeple çocuk hastalara otomatik diş firçaları da önerilebilir.

Anahtar Kelimeler: Otomatik diş firçası, Çocuklar, AğıZ Sağlı̆̆1

\footnotetext{
${ }^{1}$ Marmara University, Faculty of Dentistry, Department of Paediatric Dentistry, Istanbul

${ }^{2}$ Marmara University Pendik Training and Research Hospital
} 


\section{INTRODUCTION}

Dental biofilms are the primary etiologic factors in the two most prevalent oral diseases, dental caries and periodontal diseases. ${ }^{1,2}$ It has long been recognized that the presence of dental plaque leads to gingivitis, periodontitis and is also capable of reducing the $\mathrm{pH}$ at the surface of enamel to the levels that can cause dissolution of the hydroxyapatite crystals and initiates caries. $^{3}$ The disease can gravely affect the quality of life of children as well as adult patients, furthermore, contracting the disease at an early age puts these children at greater risk of developing caries and periodontal disease in the future. As a result, many end up requiring general anasthesia to under go treatment for a disease that is completely preventable. ${ }^{4}$ Mechanical methods for plaque control are still the most widely used and accepted. ${ }^{1,5}$ Plaque control is defined as plaque removal on a routine daily basis and preventing its reaccumulation on tooth surfaces. It is assumed that efficient bacterial plaque removal can be accomplished by brushing the teeth for two minutes twice a day, using a fluoridated toothpaste. However, patients tend to overestimate the time they spend on oral hygiene. Tooth- brushing times below the recommended 2 minutes are observed, especially when no time control is conducted. Unfortunately, effective mechanical methods of plaque control are relatively tedious, time consuming and, difficult to master in children. ${ }^{1,6}$ There arises difficulty in oral hygiene maintenance so the oral hygiene methods may need to be simplified or modified to suit the individual situation. ${ }^{4,5-10}$ Considering the characteristics of individuals, there might be advantages and disadvantages of the materials used in oral hygiene especially in brushing. Hand skills, manuplation, consuming time, having fun may be defining features for choosing the right methods and tools to encourage the children for brushing their teeth daily.
The pressure of the toothbrush head during toothbrushing seems to significantly affect the condition of the tissue in the oral cavity. According to some authors, manual toothbrushing entails the application of much higher pressure than the use of power brushes. ${ }^{1}$ ${ }^{11,12}$ Powered toothbrushes appear to be helpful in improving the oral health of physically or mentally handicapped individuals because these devices require minimal hand motion and coordination skills. Some models are designed with each bristle rotating individually and are effective plaque removers. Although previous comparative studies between powered and manual toothbrushes have led to somewhat equivocal results, however, a review study showed advantage in plaque removal and reduction in gingivitis was seen for oscillating/rotating design of power brush. ${ }^{3}$

Vibhute et al. $^{2}$ reported a meta analysis study and concluded that as no trial compared durability and reliability of using manual versus powered brushes, it is not possible to make clear recommendation of toothbrush superiority.

The aim of this study is to compare the efficacy of an electric toothbrush with that of a manual toothbrush in controlling plaque and gingivitis in a small group of children.

\section{MATERIALS AND METHODS}

Ten children ( 3 girls, 7 boys) aged ranged between 7 to 10 years old were included the study. A single investigator explained the objectives of the research to the participants and their parents and asked them to sign the informed consent form. Inclusion and exclusion criteria applied for all participants are reported in Table 1.

Table 1: Inclusion and exclusion criteria applied for the selection of participants

\begin{tabular}{|l|l|}
\hline Inclusion criteria & Exclusion criteria \\
\hline Good general health & Any systemic disease \\
\hline Minimum 20 natural teeth & $\begin{array}{l}\text { Any removable or fixed orthodontic } \\
\text { appliance }\end{array}$ \\
\hline Never used a sonic power tooth brush before & $\begin{array}{l}\text { A present history of medications } \\
\text { that are likely to affect oral health. }\end{array}$ \\
\hline dmft/DMFT $<5$ & $\begin{array}{l}\text { Bad oral health: caries, periodontal } \\
\text { diseases or oral lesions, dmft/DMFT }>5\end{array}$ \\
\hline & $\begin{array}{l}\text { physical, mental abnormality restricting free } \\
\text { movement of the hands }\end{array}$ \\
\hline
\end{tabular}


This study was planned as a randomized, single examiner, 6 weeks clinical trial with three study visit which consisted of 2 phases of 2 weeks duration each. Participants were provided with manual tooth brush (Oral-B®: ORAL B Stages for children) and powered toothbrush (Oral-BßTRIUMPH 5000 SMART GUIDE). To rule out the effect of toothpaste both group were advised to use their daily toothpaste during the study period. Bass technique for the manual brushing was demonstrated and powered electric brush was shown how to use according to the instruction and manufacturer's recommendation. After demonstration, all the participants were asked to replicate demonstrated movements on an oral model. No specific interdental cleaning aids were recommended. Participants were advised to brush at least 2 minutes. The subjects were given to familiarize and adapt to the manual and powered toothbrushes and brushing techniques, before starting the study. The following appointment was planned at two weeks after. Each child firstly used manual tooth brush. After two weeks children were given an appointment to keep oral hygiene motivation and obtain washout without changing the manual toothbrush. After four weeks from the initial session, this session is also the baseline of the powered toothbrush session, participants were asked to use powered tooth brush for two weeks.

Initial visit: Participants received an oral examination of hard and soft tissues and GC Plaque ID Gel was used for disclosing plaque. PI values were recorded for the facial and interproximal surfaces of all the teeth following use of a disclosing agent applied with a cotton applicator. Plaque evaluation was performed using Turesky modification of the Quigley and Hein index (TQHPI) ${ }^{13,14}$ and Approximal Plaque Index (API). ${ }^{15}$ All scores were recorded as baseline values of the manual session and asked the participants to use manual toothbrush for two weeks.
First visit (After 2 weeks from initial): Intraoral examination was performed and plaque was disclosed as initial visit. PI values were recorded as after manual toothbrushing session Participants were asked to keep brushing by using manual toothbrush and sheduled next appointment for two weeks after.

Second visit (After 4 weeks from initial): For second session once again initial protocol of the plaque was performed at baseline for powered toothbrush and asked participants to brush with powered device for two weeks.

Third visit (After 6 weeks from initial): The second toothbrush was tested by using same initial assessment of plaque and new plaque score was recorded following the same procedure as above.

Data Analysis: All subjects were told to inform if any problem with manual or powered toothbrush in between study period. The subjects were examined at the baseline and end of 2 weeks. At the start of 2 st phase, plaque scores were again reduced to baseline. Each time plaque and gingival status scores were recorded by a single investigator. At the end of 2 weeks, cross over was done. All measurements were performed by the same investigator. Entire mouth indexes were calculated using the following formula: index= total score/ number of examined surfaces.

Statistics: Data were statistically analyzed by using IBM SPSS Statistics 22 (IBM SPSS, Turkey). Friedman test and Wilcoxon signed rank test were used for comparisons at a significance at $\mathrm{p}<0.05$.

\section{RESULTS}

There were 10 children ( 7 boys, 3 girls) (mean age $=8.30 \pm 1.06$ ) participated at the beginning of the study. One subject dropped out after the first visit therefore, was not included in the results of this study. Another subject was unable to be present at the final phase of the study and was, hence, only included in a portion of the results. 
Dental plaque index measurements were repeated 3 times; at baseline, after manual toothbrushing, and after powered toothbrushing. Table 2 and Table 3 shows the TQHPI and API Scores baseline and after assigned toothbrushing according to their own index scale.

Table 2: tqhpi scores at beginning and after assigned tooth brushing
\begin{tabular}{|c|c|c|c|}
\hline SCORE & $\begin{array}{c}\text { Beginning } \\
(\%)\end{array}$ & $\begin{array}{c}\text { After Manual brushing } \\
(\%)\end{array}$ & $\begin{array}{c}\text { After Powered brushing } \\
(\%)\end{array}$ \\
\hline 5 & 19,5 & 8,05 & 0,4 \\
\hline 4 & 10,05 & 12,3 & 4,2 \\
\hline 3 & 18,5 & 19,4 & 13,2 \\
\hline 2 & 29,6 & 33,6 & 27,01 \\
\hline 1 & 17,4 & 12,3 & 21,3 \\
\hline 0 & 4,7 & 14,2 & 33,6 \\
\hline
\end{tabular}

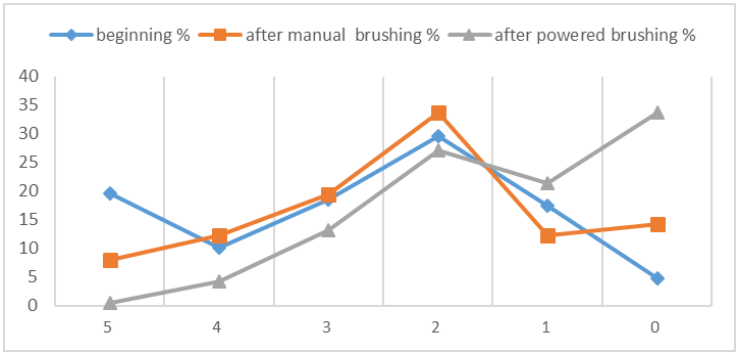

Fig1: TQHPI at beginning and after assiggned tooth brushing

Table 3 : API Scores At Baseline And After Assisgned Tooth Brushing

\begin{tabular}{|c|c|c|c|}
\hline SCORES & $\begin{array}{c}\text { Beginning } \\
(\%)\end{array}$ & $\begin{array}{c}\text { After Manual Brushing } \\
(\%)\end{array}$ & $\begin{array}{c}\text { After Powered Brushing } \\
(\%)\end{array}$ \\
\hline 1 & 88,8 & 83,4 & 56,4 \\
\hline 0 & 11,2 & 16,6 & 43,6 \\
\hline
\end{tabular}

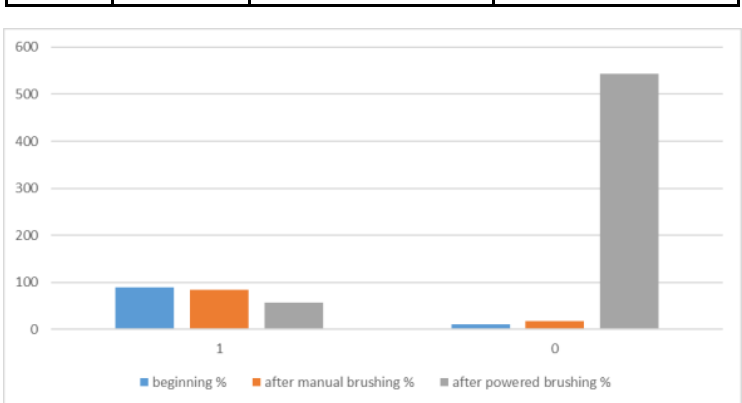

Fig 2: API at Beginning and After Assigned Tooth Brushing

The whole-mouth mean plaque scores for each toothbrush type are shown in Table 4. The whole mouth TQHPI and API were significantly different at after Powered Tooth brushing $\quad(\mathrm{p}=0.005, \mathrm{p}=0.012)$. Noticeable decrease was obtained in mean value at baseline and after powered tooth brushing. Powered toothbrush resulted in a larger reduction in plaque score when compared to the manual one. Despite the decline observed in the manual tooth brushing, this reduction is not statistically significant $(\mathrm{p}=0.173, \mathrm{p}=0.345)$.
Table 4: Comparison of Whole Mouth Plaque Indices Among Assigned Toothbrushes

\begin{tabular}{|c|c|c|c|c|c|c|}
\hline $\begin{array}{c}\text { Assigned } \\
\text { toothbrush }\end{array}$ & $\begin{array}{c}\text { TQHPI at } \\
\text { baseline } \\
\text { meant } \pm \text { DD } \\
\text { (median) }\end{array}$ & $\begin{array}{c}\text { TQHPI } \\
\text { 2 weeks } \\
\text { follow up } \\
\text { meanns } \\
\text { (median) }\end{array}$ & $\mathrm{p}$ & $\begin{array}{c}\text { API at baseline } \\
\text { meantSD } \\
\text { (median) }\end{array}$ & $\begin{array}{c}\text { API } \\
\text { 2weeks } \\
\text { follow up } \\
\text { meantSD } \\
\text { (median) }\end{array}$ & $\mathrm{p}$ \\
\hline $\begin{array}{c}\text { Manual } \\
\text { toothbrush }\end{array}$ & $2,71 \pm 0,8(2,54)$ & $2,25 \pm 0,81(2,45)$ & $\mathbf{0 . 1 7 3}$ & $0,88 \pm 0,17(1)$ & 0.83 & $\mathbf{0 , 3 4 5}$ \\
\hline $\begin{array}{c}\text { Powered } \\
\text { toothbrush }\end{array}$ & $2,25 \pm 0,81(2,45)$ & $1,37 \pm 0,64(1,34)$ & $\mathbf{0 . 0 0 5 * *}$ & $0,83 \pm 0,14(0,78)$ & 0,55 & $\mathbf{0 , 0 1 2}$ \\
\hline
\end{tabular}

Wilcoxon sign test $* * p<0.01 * p<0.05$

An evaluation was also performed to see if there were any differences among toothbrushes types at baseline and 6 weeks follow up. There was a statistically significant interaction between the toothbrush type and changes in TQHPI and API plaque score from baseline to the 2-week follow-up visit $\left({ }^{* *} p<0.01,{ }^{*} p<0.05\right)$. (Table 5). Statistics determined the most significant relationship was observed between baseline-post powered brushing and between manual-powered brushing in both TQHPI and API values $\left(\mathrm{p}=0.008^{* *}, \mathrm{p}=0.005^{* *}, \mathrm{p}=0.018^{*}\right.$, $\mathrm{p}=0.012^{*}$ ).

Table 5: Interaction Between The Toothbrush Type and Baseline
\begin{tabular}{|l|c|c|}
\hline & $\begin{array}{c}\text { TQHPI } \\
(\mathrm{p})\end{array}$ & $\begin{array}{c}\text { API } \\
(\mathrm{p})\end{array}$ \\
\hline Beginning \& Manual Brushing & 0,173 & 0,345 \\
\hline Beginning \& Powered Brushing & $0,008^{* *}$ & $0,018^{*}$ \\
\hline Manual Brushing \& Powered & $0,005^{* *}$ & $0,012^{*}$ \\
\hline
\end{tabular}

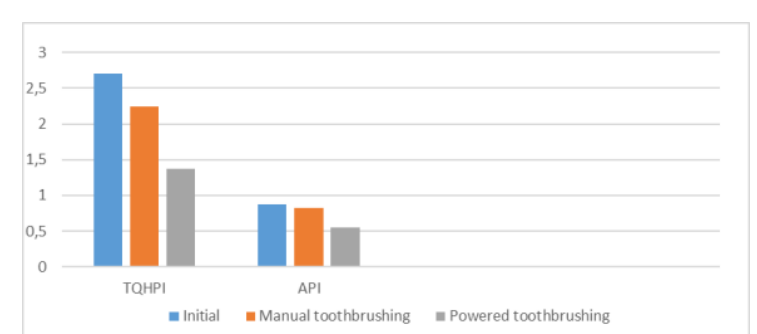

Fig 3: Plaque index reductions for the tested manual and powered toothbrushes

\section{DISCUSSION}

The prevetion procedure of oral hygiene depends on the ability and motivation of individual patients. ${ }^{16}$ Both manual and power toothbrushes have increased the ability to remove plaque, although the effectiveness of manual toothbrush is still limited by manual dexterity and skill of the user. ${ }^{1,17}$ Powered toothbrushes have partially overcome this limitation with the added advantage of simplifying the brushing technique and increasing the motivation to brush regularly. ${ }^{5} \mathrm{In}$ 
our study we have evaluated the potential advantage of powered toothbrush over manual toothbrush in plaque control for children.

Turesky modification of the Quigley Hein Index (TQHPI) and Approximal Plaque Index (API) were used for plaque score with GC Plaque ID gel in the study. This clinical trial was designed to define the toohbrushing efficacy on not only smooth surface but also approximal surfaces. Therefore, no additional interdental oral hygiene tools were recommended. Re et $a l .{ }^{5}$, Silvermann et al. ${ }^{19}$, Sheikh-Al-Eslamian et $a l .{ }^{18}$ used the same index to record the dental plaque. Yousaf et al. ${ }^{3}$ studied with Silness- Löe plaque index, because it can be recorded easily and evaluated in a simple way. Furthermore, The Rustogi Modified Navy Plaque Index was used by Klukowska et al. ${ }^{20}$ for analyzing of difficult to clean surfaces such as the gingival margin and approximate areas. It is more difficult to clean approximal and gingival margin areas to sustain gingival health by the ordinary brusher. ${ }^{21,} 22$ A large research by Morris et al. ${ }^{23}$ concluded that even when adults brushed immediately before an examination, a non disclosed plaque was seen on the one-third of the teeth. Reguarding this situation, it is much more difficult for children to remove dental plaque with manual brushes all the surfaces of tooth.

Sharma et al. ${ }^{24}$ made their research for 4 weeks and concluded substantial improvements in plaque coverage and reported that both brushes had been well tolerated. Re et al designed the study for three appointments were sheduld one week apart and asked the participants to refrain from all oral hygiene measures 23-25 $\mathrm{h}$ prior to the appointment their teeth and brush teet at visit on site. ${ }^{5}$ Silverman et al. ${ }^{19}$ have studied for 6 weeks on 4 to 5 years old children by dividing the participants in to three groups according to the brush types and asked to brush their allocated toothbrushes at home fort he next 5 to 7 weeks. Goyal et al. ${ }^{7}$ assigned the subjects by lottery method to one of two groups providing the groups to start brushing manual or powered tooth brush randomly for first three months and order was reversed for following three months. Jain et al compared the efficacy of powered and manual toothbrushes in controlling plague and gingivitis over a 6 week period. On 14th and 42nd days, significant results was shown by the subjects in the powered group. ${ }^{6}$ The partcipants in our study firstly used manual toothbrush for two weeks and following two weeks they used powered one. Between manual and powered brushes washout sesssion were assigned. Therefore the trial was completed in six weeks.

There are overmuch clinical studies that have shown a relationship between oral hygiene status and the amount of dental plaque. In plaque control, both two brushes have significantly effect but powered toothbrush has better effect. Lazarescu et al. Jongenelis, Baab and Johnson, and Preber et al. had obtained similar results in their studies. ${ }^{25,26,27,28}$ However, William et al. ${ }^{29}$ resulted their studies as both brushes were equally effective in removing biofilm.

According to the Jain et al findings in oral hygiene score; no statistically significant difference was found between the manual toothbrush and powered toothbrush groups. However; Jain concluded that; powered toothbrushes offer an individual the ability to brush the teeth optimally to remove plaque and improve gingival health. ${ }^{6}$ Silverman reported that the powered one performed significantly better in the 6 weeks trial for dental plaque removal. ${ }^{19}$ In a study by Heasman, they observed lower plaque index in powered toothbrush users in comparison with manual toothbrush users especially at the inter proximal surfaces. ${ }^{30}$

Cochrane database showed that there was moderate quality evidence that powered toothbrushes provide a statistically significant benefit compared with manual toothbrushes with regard to the 
reduction of plaque in both the short term and long term. ${ }^{31}$

In a review study by Robinson et al. reported that 42 studies were evaluated regarding powered and manual toothbrushes use and no significant difference was found in plaque removal between the powered toothbrushes with counter oscillation, side-toside, circular ultrasonic or ionic movements, and manual toothbrush. However, Robinson added; powered toothbrushes with rotation oscillation movement acted more efficiently than manual toothbrushes. ${ }^{32}$ According to metaanalysis by Vibhute and Vandana, there was no significant difference between the electric toothbrush and the manual toothbrush in plaque index. Although ionic and manual brushes showed statistically significant reduction of plaque index from baseline. Effect size of pooled data demonstrated a very large effect of using powered toothbrush for plaque removal as compared to manual toothbrush. ${ }^{2}$ Similirly, we found reduction the plaque aqumulation not only smooth surfaces but also interproximal surfaces by using powered toothbrush.

\section{CONCLUSION}

In children without any previous experience of powered toothbrush and any training from parents, powered tooth brush showed more reduction in plaque compared to manual one. Considering the limitations of the study group, powered toothbrush might be recommended as effective and safe as manual toothbrush for children.

\section{Bullet Points:}

$\checkmark \quad$ To observe if the children who have just started to brush their teeth by their selves, use powered toothbrush as effective as manual toothbrush

$\checkmark \quad$ To find out if powered toothbrush do provide an effective dental plaque reduction a conventional manual toothbrush
There is lack of comparative study on powered toothbrush versus manual toothbrush in children

\section{Acknowledgements:}

The study was supported by a research grant from The Marmara University Scientific Research Committee (BAP-KO) with project numbers SAG-D-130515-0173.

\section{REFERENCES}

1. Garcia-Carrillo A, Jover A, Pla R, et al. Manual versus sonic powered toothbrushing in patients with intellectual disability: a clusterrandomised clinical trial. J Clin Periodontol. 2016.

2. Vibhute A, Vandana KL. The effectiveness of manual versus powered toothbrushes for plaque removal and gingival health: A metaanalysis. J Indian Soc Periodontol. 2012;16(2):156-160.

3. Yousaf A. AN, Manzoor AM., Yasmin R. Comparison of Powered and Manual Toothbrushes in Removal of Plaque. Pakistan Oral \& Dental Journal. 2012;32(1):120-123.

4. Aljafari A, Rice C, Gallagher JE, et al. An oral health education video game for high caries risk children: study protocol for a randomized controlled trial. Trials. 2015;16:237.

5. Re D, Augusti G, Battaglia D, et al. Is a new sonic toothbrush more effective in plaque removal than a manual toothbrush? Eur J Paediatr Dent. 2015;16(1):13-18.

6. Jain Y. A comparison of the efficacy of powered and manual toothbrushes in controlling plaque and gingivitis: a clinical study. Clin Cosmet Investig Dent. 2013;5:3-9.

7. Goyal S, Thomas BS, Bhat KM, et al. Manual toothbrushing reinforced with audiovisual instruction versus powered toothbrushing among institutionalized mentally challenged subjects--a randomized cross-over clinical trial. Med Oral Patol Oral Cir Bucal. 2011;16(3):e359-364. 
8. Pine CM, McGoldrick PM, Burnside G, et al. An intervention programme to establish regular toothbrushing: understanding parents' beliefs and motivating children. Int Dent $\mathrm{J}$. 2000;Suppl Creating A Successful:312-323.

9. Gray-Burrows KA, Day PF, Marshman Z, et al. Using intervention mapping to develop a home-based parental-supervised toothbrushing intervention for young children. Implement Sci. 2016;11(1):61.

10.Cunha-Cruz J, Milgrom P, Shirtcliff RM, et al. "Everybody brush!": protocol for a parallelgroup randomized controlled trial of a familyfocused primary prevention program with distribution of oral hygiene products and education to increase frequency of toothbrushing. JMIR Res Protoc. 2015;4(2):e58.

11.Ghassemi A, Vorwerk L, Hooper W, et al. Comparative plaque removal efficacy of a new children's powered toothbrush and a manual toothbrush. J Clin Dent. 2013;24(1):1-4.

12. Mielczarek A. BT, Knopka T. An Assessment of the Effect of Manual and Electric Toothbrushes on Hard and Soft Oral Tissue. Dent Med Probl. 2013;50(4):472-475.

13. Turesky S, Gilmore ND, Glickman I. Reduced plaque formation by the chloromethyl analogue of victamine C. J Periodontol. 1970;41(1):41-43.

14. Quigley GA, Hein JW. Comparative cleansing efficiency of manual and power brushing. J Am Dent Assoc. 1962;65:26-29.

15. Kallar S, Pandit IK, Srivastava N, et al. Plaque removal efficacy of powered and manual toothbrushes under supervised and unsupervised conditions: a comparative clinical study. J Indian Soc Pedod Prev Dent. 2011;29(3):235-238.

16. Ferrazzano GF, Cantile T, Sangianantoni G, et al. Effectiveness of a motivation method on the oral hygiene of children. Eur J Paediatr Dent. 2008;9(4):183-187.
17. Heasman P. Power toothbrushes. Efficacy of a unique gum protection system with an interproximal tip. Introduction. J Clin Dent. 2001;12(1):1.

18. Sheikh-Al-Eslamian SM. YN, Monir SES., Kadkhodazadeh M. Comparison of Manual and Electric Toothbrush in Dental Plaque Removal: Clinical Trial. Avicenna J Dent Res. 2014;6(1).

19. Silverman J, Rosivack RG, Matheson PB, et al. Comparison of powered and manual toothbrushes for plaque removal by 4- to 5year-old children. Pediatr Dent. 2004;26(3):225-230.

20.Klukowska M, Grender JM, Goyal CR, et al. 8 -week evaluation of anti-plaque and antigingivitis benefits of a unique multi-directional power toothbrush versus a sonic control toothbrush. Am J Dent. 2012;25 Spec No $\mathrm{A}(\mathrm{A}): 27 \mathrm{~A}-32 \mathrm{~A}$.

21. Sharma NC, Lyle DM, Qaqish JG, et al. Comparison of two power interdental cleaning devices on plaque removal. J Clin Dent. 2012;23(1):17-21.

22. Sharma NC, Lyle DM, Qaqish JG, et al. Comparison of two power interdental cleaning devices on the reduction of gingivitis. J Clin Dent. 2012;23(1):22-26.

23.Morris AJ, Steele J, White DA. The oral cleanliness and periodontal health of UK adults in 1998. Br Dent J. 2001;191(4):186-192.

24. Sharma NC, Klukowska M, Mielczarek A, et al. A 4-week clinical comparison of a novel multi-directional power brush to a manual toothbrush in the reduction of gingivitis and plaque. Am J Dent. 2012;25 Spec No A(A):14A-20A.

25.Lazarescu D, Boccaneala S, Illiescu A, et al. Efficacy of plaque removal and learning effect of a powered and a manual toothbrush. J Clin Periodontol. 2003;30(8):726-731.

26.Jongenelis AP, Wiedemann W. A comparison of plaque removal effectiveness of an electric versus a manual toothbrush in 
children. ASDC J Dent Child. 1997;64(3):176182,165 .

27.Baab DA, Johnson RH. The effect of a new electric toothbrush on supragingival plaque and gingivitis. J Periodontol. 1989;60(6):336-341.

28.Preber H, Ylipaa V, Bergstrom J, et al. A comparative study of plaque removing efficiency using rotary electric and manual toothbrushes. Swed Dent J. 1991;15(5):229234.

29.Williams MI, Vazquez J, Cummins D. Clinical comparison of a new manual toothbrush on breath volatile sulfur compounds. Compend Contin Educ Dent. 2004;25(10 Suppl 2):22-27.

30.Heasman PA, Stacey F, Heasman L, et al. A comparative study of the Philips HP 735, Braun/Oral B D7 and the Oral B 35 Advantage toothbrushes. J Clin Periodontol. 1999;26(2):85-90.
31. Yaacob M, Worthington HV, Deacon SA, et al. Powered versus manual toothbrushing for oral health. Cochrane Database Syst Rev. 2014(6):CD002281.

32. Robinson PG, Deacon SA, Deery C, et al. Manual versus powered toothbrushing for oral health. Cochrane Database Syst Rev. 2005(2):CD002281.

\section{Corresponding Author}

Müesser Ahu DURHAN

Marmara University

Faculty of Dentistry

Department of Paediatric Dentistry

Maltepe, Basıbuyuk Saglık Kampusu, 34854, Istanbul, Turkey

Phone : +90216421 1621

Fax : : +902164210613

E-mail : ahudurhan@hotmail.com 